Miłaszewicz D., Sustainable competitivenes - analisis of economies at various levels of development, „Ekonomia i Prawo. Economics and Law.”, Polszakiewicz B., Boehlke J. (ed.), Vol. 13, No. 4/2014, pp. 511-522. DOI: http://dx.doi.org/10.12775/EiP.2014.036.

\title{
SUSTAINABLE COMPETITIVENES - ANALISIS OF ECONOMIES AT VARIOUS LEVELS OF DEVELOPMENT
}

\author{
SUMMARY
}

Hitherto conducted analyses of international competitiveness paid special attention to economic aspects. The article places particular emphasis on other aspects of human activity that reflect people's involvement in sustainable development as well as have effect on development potential and competitive capacity of economies. The concept of sustainable development is an interdisciplinary approach to the analysis of international competitiveness introduced by World Economic Forum (WEF). In 2012, WEF proposed a methodology for measuring so-called sustainable international competitiveness. The present paper is aimed at analyzing sustainable international competitiveness of five groups of states in order to identify factors favourable or detrimental to their competitive ability and potential. The analysis presented in the article indicates that only in the case of the richest and at the same time the most competitive (in conventional terms) countries, factors determining social and environmental sustainability have a positive effect on the competitive capacity and development potential of these states. As for the remaining four groups of countries, environmental and social factors contribute to limited competitive capacity and development potential of the economies.

Keywords: general outlook and conditions, economic development, policy

JEL Classification: E66, F63, F68

* Danuta Miłaszewicz, Szczecin University, Faculty of Economics and Management, Department of Macroeconomics, ul. Mickiewicza 64/66, 71-101 Szczecin, phone: +489144420 91, e-mail: dmilasz@wneiz.pl. 


\section{INTRODUCTION}

Nowadays competitiveness is a common phenomenon. As for definitions of competitiveness accepted by particular fields or areas of human activity, certain similarities and correlations can be found among particular types of competition ${ }^{1}$. Nevertheless, as a result of competition someone wins and someone loses, regardless of the domain of human activity as part of which the rivalry takes place.

Just as various aspects of human activity cannot be discussed in isolation, similarities and relationship among particular types and aspects of competition should be analysed in reference to one another. Furthermore, research on competitiveness should have an interdisciplinary character. This remark is particularly significant in the context of sustainable socio-economic development which is to provide both present and future generations with growing prosperity. In other words, no one should be excluded from positive consequences following from the aforementioned growth and no area of development should be discriminated. The idea of sustainable development is based on such notions as equity, partnership, respect and cooperation at various levels, namely local, international and global. Therefore, it seems to be contradictory to competition treated as a rivalry.

Hitherto conducted analyses of international competitiveness of economies were based on economic aspects. This ought to be changed and attention should be paid to other aspects of human activity that reflect people's involvement in sustainable socio-economic development. The concept of national sustainable development is a recommendation for such a change and is an interdisciplinary approach to the analysis of international competitiveness introduced by World Economic Forum (WEF). In line with a new methodology, apart from selected institutional and social factors, the research addressed economic factors determining competitiveness. In 2012, WEF proposed a methodology for measuring so-called sustainable international competitiveness. The present paper is aimed at analysing sustainable international competitiveness of five groups of states in order to identify factors favourable or detrimental to their competitive ability and potential. The analysis will be based on the aforementioned methodology and ranking.

${ }^{1}$ M.S. Snow, Competition as a discovery procedure, „The Quarterly Journal of Austrian Economics", Vol. 5, No. 3/2002, p. 9. 


\section{INTERNATIONAL COMPETITIVENESS AND ITS MEASUREMENT}

Economic competition is most common and best known to modern societies. According to Stankiewicz, competition is "... a phenomenon that involves a rivalry between individuals attempting to achieve certain (analogous) goals, which implies that actions taken by some individuals to accomplish their objectives make it difficult (or even impossible) for others to accomplish their goals" ${ }^{2}$. Although it is regarded a process that brings about a number of positive changes, its numerous negative consequences should not be neglected. To be more specific, attention should be paid to certain limitations on rivalry. A review of sources, aspects, types and plausible results of economic competition, presented in the literature on the subject, is of major use for defining conditions under which competition is considered a positive and under which - a negative phenomenon (producing negative consequences), when it is necessary to intervene in the process of competition, and what effects individuals, societies and economies experience as a results of competition ${ }^{3}$.

Competitiveness is an element of competition and a characteristic of its participants. It can be defined as the ability to: compete, i.e. act and survive in competitive environment $t^{4}$, achieve success on the market ${ }^{5}$, fight for economic survival in conditions of fierce competition ${ }^{6}$. Competitiveness may be the case with products and enterprises (microeconomic perspective), branches of industries and regions (mezoeconomic perspective), nations and econo-

2 M.J. Stankiewicz, Konkurencyjność przedsiębiorstwa, [in:] M.J. Stankiewicz (ed.), Budowanie konkurencyjności przedsiębiorstwa w warunkach globalizacji, Dom Organizatora, Toruń 2005, p. 19.

${ }^{3}$ For example E. Toder looks at competition for what he terms five possible areas in which zero-sum competition may exist: competition for (1) labor supply, (2) financial and physical capital, (3) corporate residence and intangible capital, (4) tax revenues from multinational corporations, and (5) natural resources. E. Toder, International Competitiveness: Who Competes Against Whom and for What?, Urban-Brookings Tax Policy Center 2012, http://taxpolicycenter. org/UploadedPDF/412477-international-competitiveness.pdf (24.10.2013).

${ }_{4}^{4}$ Gorynia M. (ed.), Luka konkurencyjna na poziomie przedsiębiorstwa a przystapienie Polski do Unii Europejskiej, Wydawnictwo AE w Poznaniu, Poznań 2002, p. 48.

${ }^{5}$ K. Kłosiński, Sektor ustug w procesie podnoszenia konkurencyjności gospodarki, IRWiK, Warszawa 2003, p. 23.

${ }^{6}$ W. Bieńkowski, Konkurencyjność gospodarki polskiej w przededniu wejścia do Unii Europejskiej. Czy rząd może być bardziej aktywny? \{in:] E. Latoszek (ed.), Unia Europejska wobec procesów integracyjnych. Wyzwania dla Polski, WSHiFM, Warszawa 2000, p. 96. 
mies (macroeconomic perspective), as well as supranational and international organizations (megaeconomic perspective) ${ }^{7}$.

The competitiveness of economies, referred to as their international competitiveness, is defined in a number of ways. However, international competitiveness should be understood in a wider context, e.g. the competitiveness of the entire socio-economic system which depends not only on the effectiveness of enterprises themselves, but also on the efficiency of state (with reference to its structures and institutions) ${ }^{8}$ and society (with reference to its history, culture, social attitudes and norms).

International competitiveness can be understood in the following ways:

- in an essence-based perspective (in a narrow sense) it is referred to as current ability of entities to operate in a given country in order to derive higher (or comparable) benefits from the participation in international division of labour than benefits gained";

- in a factor-based perspective (in a broad sense) it is referred to as the ability to compete, i.e. derive long-term benefits from economic foreign relations;

- in an outcome-based perspective it is referred to as the position of competitive economy or competitiveness understood in a static way; it characterizes the level of economic development ${ }^{10}$.

Nations and economies compete with one another in order to facilitate socio-economic development and therefore bridge a development gap ${ }^{11}$. Hence, international competitiveness manifests itself fully in comparison with

${ }^{7}$ J. Misala, Międzynarodowa konkurencyjnośc gospodarki narodowej, PWE, Warszawa 2011, p. 12 .

${ }^{8}$ See for more on the role of factors provided by state to achieve macroeconomic stability and world competitiveness: A. Jafarnejad, R. Ghasemi, B. Abdullahi, A. Esmailzadeh, $R e-$ lationship between Macroeconomic Environment and Technological Readiness: A Secondary Analysis of Countries Global Competitiveness, „European Journal of Social Sciences”, No. 31/2011, p. 123.

9 J. Misala, Międzynarodowa konkurencyjnośc gospodarki narodowej; wybrane aspekty teoretyczne, [in:] Czynniki i miary międzynarodowej konkurencyjności gospodarek w kontekście globalizacji wstępne wyniki badań, „Prace i Materiały”, No. 264. Instytut Gospodarki Światowej, Warszawa 2008, p. 60. Different approach to international competitiveness, taking account of the participation of modern countries in global value chains, is proposed by: M. Timmer, B. Los, R. Stehrer, Rethinking competitiveness: The global value chain revolution, Gaaitzen de Vries 2013, http:// www.voxeu.org/article/rethinking-competitiveness-global-value-chain-revolution, (26.10.2013).

${ }^{10}$ W. Bieńkowski, Reganomika i jej wptyw na konkurencyjność gospodarki amerykańskiej, Wydawnictwo Naukowe PWN, Warszawa 1995, p. 34-36.

${ }^{11} \mathrm{P}$. Swagel note that of the many indicators of international competitiveness that have been suggested in the literature, relatively few are directly linked to measures of economic prosperity. See: Swagel F. International Competiveness, [in:] K.A. Hassett (ed.), Rethinking Competitiveness, American Enterprise Institute Press, Washington 2012, p. 278-302. 
other economies. If examined in a wider context, i.e. as a characteristic of the entire socio-economic system, competitive advantage and possibility of bridging the development gap depend on differences between economic structures, institutions (formal and informal), national values, history, tradition, culture and social capital. According to Porter, the group of factors can be referred to as a national base that lays foundations for any action and at the same may foster or hinder the elimination of differences in the level of socio-economic development ${ }^{12}$. If attention is paid only to selected elements and others are neglected, the evaluation of the competitiveness of a given nation may indicate a relative advantage of this nation's only in a narrow scope of activity. On the other hand, comprehensive evaluation of competitiveness (competitive ability and position) of economies allows for identifying sources of opportunities and threats to competitiveness that are typical of a given society.

"Global Competitiveness Report", published by World Economic Forum (WEF), is based on such an approach and defines international competitiveness as „...the set of institutions, policies, and factors that determine the level of productivity of a country. The level of productivity, in turn, sets the level of prosperity that can be reached by an economy ${ }^{13}$ ". Understood in such a way, international competitiveness may be subject to change, and critical analysis of competitive potential shown by economy should provide information concerning the direction of changes as well as mechanisms or factors to be activated in order to increase competitive ability of a given economy in the future.

For the purpose of determining the level of international competitiveness $^{14}$ of economies WEF has been using Global Competitiveness Index (GCI) to perform a comprehensive analysis of international competitiveness of states based on micro- and macroeconomic foundations of competitiveness and a number of institutional and social factors. Higher value of the index entails higher level of competitiveness ${ }^{15}$. Competitiveness of every econo-

${ }_{12}$ M. Porter, Postawy, wartości i przekonania a makroekonomia dobrobytu, [in:] L.E. Harrison, S.P. Huntington (ed.), Kultura ma znaczenie, Wydawnictwo Zysk i S-ka, Warszawa 2003, p. $59-60$.

${ }_{13}$ World Economic Forum, The Global Competitiveness Report 2013-2014, Geneva 2013, p. 4.

${ }^{14}$ See for description and assessment of alternative measures of world competitiveness of a country: S. Globerman, G. Georgopoulos, Regulation And The International Competitiveness of The U.S. Economy, Mercatus Center at George Mason University, 2012, http://mercatus.org/sites/ default/files/InterntlCompetitiveness_Globerman_v1-0_1.pdf (25.10.2013), p. 7-14.

${ }_{15}$ For more information on GCI methodology see: World Economic Forum, The Global Competitiveness Report 2007-2008, Geneva 2008, p. 45-47. 
my is determined in line with certain principles and takes account of certain elements. On this basis, WFE creates rankings of competitiveness.

GCI has been created based on over 100 elements (114 in 2013) that reflect various aspects of international competitiveness of economies. The elements are grouped into 12 pillars and divided into three sections, namely basic conditions, factors enhancing effectiveness and factors enhancing innovativeness. Such an arrangement allows for identifying three subindexes that make up GCI. Thanks to dividing all the pillars of competitiveness into three groups, it is possible to create a hierarchy based on the importance of conditions to be met so that a given economy could enter a higher stage of development. Needless to say, conditions from the first-mentioned group enable the economy to accomplish such a goal. Similar situation is observed in the case of factors enhancing effectiveness (representing the second group), i.e. they enable the economy to enter the third phase of development.

Table 1. Weight placed on particular groups of factors determining competitiveness (subindexes) in different phases of economic development

\begin{tabular}{|l|c|c|c|c|c|}
\hline \multicolumn{1}{|c|}{ GROUP OF COUNTRIES } & 1 & 2 & 3 & 4 & 5 \\
\hline Stages of development & Stage I & Stage I/II & Stage II & Stage II/III & Stage III \\
\hline GDP per capita (US\$) & $<2,000$ & $2,000-2,999$ & $3,000-8,999$ & $9,000-17,000$ & $>17,000$ \\
\hline Weight for basic requirements subindex & 0,60 & $0,40-060$ & 0,40 & $0,20-0,40$ & 0,20 \\
\hline Weight for efficiency enhancers subindex & 0,35 & $0,35-0,50$ & 0,50 & 0,50 & 0,50 \\
\hline $\begin{array}{l}\text { Weight for innovation and sophistication } \\
\text { factors }\end{array}$ & 0,05 & $0,05-0,10$ & 0,10 & $0,10-0,30$ & 0,30 \\
\hline
\end{tabular}

Source: study on the basis: World Economic Forum, The Global Competitiveness Report 2011-2012, Genewa 2011, s. 10.

All the pillars of competitiveness are interrelated and complement or even enhance one another. Nevertheless, each may affect competitiveness to a varying degree, depending on development phase completed by a given economy. WEF differentiates between three main phases of economic development and two intermediate phases. In this way, the countries have been divided into 5 groups (table 1). WEF used two criteria to allocate countries into stages of development. The first is the level of GDP per capita at market exchange rates. For economies with a high dependency on mineral resources, GDP per capita is not the sole criterion for the determination of the stage of development. A second criterion is used to adjust for countries that, based on income, would have moved beyond stage 1 , but where prosperity is based on the extraction of resources. This is measured by the share of exports of min- 
eral goods in total exports (goods and services), and assumes that countries that export more than $70 \%$ mineral products (measured using a five-year average) are to a large extent factor driven.

\section{SUSTAINABILITY COMPETITIVENESS AND ITS MEASUREMENT}

Economies competing on an international arena are orientated mainly toward accomplishing economic goals that are to improve the standard of living. These objectives are very often contradictory to environmental and social goals. Still, a great number of non-economic elements determine the standard of living and social prosperity in a long-term perspective. A sort of incompatibility among these goals in classical theories of growth (which failed to account for reasons behind growing disproportions in income generated by competing countries) and growing number of actions harmful to the environment have contributed to the idea of sustainable social development two decades ago.

Today the idea of sustainable development is treated as a certain kind of vision and philosophy, on which the new paradigm of stable, long-term development is based, and it relates to the whole human community and future generations. It is a concept on which many countries have based their economic policy-making and assessment of social progress for several years. It is usually emphasised that the sustainable development concept concerns economic, social and environmental sustainabilities, i.e. three systems whose interests it is trying to trade off.

The transition of the idea of sustainable development on a particular conception of a social development program requires simultaneous consideration of all these dimensions. This demands a harmonious blend of diverse objectives in the ultimate goal of development (welfare/well-being is widely considered to be this goal), and the creation of integrated governance, resulting from the concept of sustainable and stable development in accordance with the principles of justice within and between generations ${ }^{16}$.

Although the creation of GCI is based on over a hundred factors of competitiveness, calculating it for particular economies does not take account of aspects important from the perspective of sustainability and demonstrating a functional relationship with competitive ability or development potential

16 B. Piontek, Wspótczesne uwarunkowania rozwoju spoteczno-gospodarczego (ujęcie syntetyczne), „Problemy Ekorozwoju. Problems of Sustainable Development”, Vol. 5, No. 2/2010, p. 117-124. 
of these economies. Having recognized the necessity to analyse aspects of sustainable development, WEF opened a discussion on the relationship between international competitiveness and environmental or social sustainability. As a result, the definition of sustainable international competitiveness and suggestions concerning the methodology for its measurement were put forward.

The overall definition of sustainable competitiveness explain that it "...is the set of institutions, policies and factors that make a nation remain productive over the longer term while ensuring social and environmental sustainability" ${ }^{\prime 7}$. Based on the aforementioned definition and hitherto followed procedure for evaluating the competitiveness of economies with the use of GCI, WEF proposed the methodology of the sustainability-adjusted Global Competitiveness Index (GCIs+e). It takes account of two additional pillars of sustainability, namely social and environmental. Each of the two pillars consists of three elements characterized by three indicators ${ }^{18}$. Each indicator has been given an equal weight within each pillar.

Table 2. Adjustment to the GCl scores by sustainability indicators and GDP per capita (USD)

\begin{tabular}{|c|c|c|c|c|c|c|}
\hline \multicolumn{2}{|c|}{ SPECIFICATION } & GCI 2013-2014 & GCIS & GCIE & GCIS+E & GDP PER CAPITA \\
\hline \multirow{2}{*}{ Group 1 } & average value & 3.86 & 3.25 & 3.63 & 3.44 & 1135.83 \\
\cline { 2 - 7 } & coefficient of variation & 0.07 & 0.11 & 0.09 & 0.09 & 0.40 \\
\hline \multirow{2}{*}{ Group 2 } & average vale & 4.06 & 3.72 & 3.60 & 3.66 & 4737.80 \\
\cline { 2 - 7 } & coefficient of variation & 0.07 & 0.07 & 0.12 & 0.09 & 0.39 \\
\hline \multirow{2}{*}{ Gorup 3 } & average value & 4.17 & 3.80 & 3.86 & 3.83 & 5799.27 \\
\cline { 2 - 7 } & coefficient of variation & 0.07 & 0.11 & 0.09 & 0.09 & 0.33 \\
\hline \multirow{3}{*}{ Group 4 } & average value & 4.36 & 4.32 & 4.22 & 4.27 & 12967.31 \\
\cline { 2 - 7 } & coefficient of variation & 0.06 & 0.09 & 0.11 & 0.09 & 0.16 \\
\hline \multirow{2}{*}{ Group 5 } & average value & 5.00 & 5.54 & 5.18 & 5.36 & 43627.57 \\
\cline { 2 - 7 } & coefficient of variation & 0.10 & 0.14 & 0.14 & 0.14 & 0.40 \\
\hline
\end{tabular}

Source: own study.

${ }_{17}$ World Economic Forum, The Global Competitiveness Report 2013-2014, Geneva 2013, p. 55 .

${ }^{18}$ For social sustainability: population's access to basic necessities, vulnerability to economic exclusion, social cohesion. For social sustainability: environmental policy, use of renewable resources, degradation of the environment. 
GCIs+e calculated for particular economies will be used in the present paper for further analysis of five groups of countries and to be more specific in order to identify factors favourable and detrimental to their competitive ability and development potential. Table 2 presents the results of the analysis. The findings indicate that each group represents a relatively uniform set and therefore it is to some extent acceptable to treat them as a conventional whole.

Comparison between GCI and GCIs, GCIe, GCIs+e suggests that only in the group of the richest and at the same time the most competitive countries, social and environmental factors exert a positive effect on their current competitive ability. As far as this group of states is concerned, appropriate conditions for social sustainability have a particularly positive influence on international competitiveness. Broad social access to basic necessities and social cohesion provide conditions favourable to inclusive economic growth in which all the citizens participate and make use of. Furthermore, limited economic vulnerability to shocks contributes to a more stable development. These countries are characterized by limited degradation of the environment (thanks to a proper protection policy) and use renewable sources of energy in production and consumption. Therefore, positively evaluated dimensions of environmental sustainability contribute to a higher rating of competitive ability demonstrated by this group of states. GCIs+e for this group of countries are 7\% higher than GCI.

As for the remaining groups of states, environmental and social factors to a varying degree reduce current competitive ability and development potential of these economies. As for the negative effect exerted by social factors, the first group of states experience it to the greatest extent. Average GCIe in this group is nearly $16 \%$ lower than GCI. These are mainly poor and underdeveloped states situated in Africa (e.g. Bangladesh, Cameroon, Chad, Ethiopia, Kenya, Rwanda) which have an extremely limited access to basic necessities (sanitation, drinking water, health care) and where social cohesion is hardly observed. That is why in no other group under analysis social pillar of sustainability affects competitive ability in such a detrimental way. Furthermore, environmental factors also exercise a negative influence in this group. However, their effect on sustainable international competitiveness is more adverse in the states forming group no. 2. These countries are currently in between 1 st and 2nd phase of development. Although the average level of development of the aforementioned states, reflected in GDP per capita (table 2), indicates they have already entered 2nd stage of development (table 1), the other qualification criterion adopted by WEF with reference to economies, implies they have entered an intermediate stage (i.e. in between factor-driven economies 
group and efficiency-driven economies group). This group is represented by economies whose development is based on crude oil mining (e.g. Iran, $\mathrm{Ku}-$ wait, Saudi Arabia, Venezuela). The main reason behind such a classification is a considerable damage to the environment observed in these countries (reflected in so-called ecological footprint of these economies). Most of them do not use renewable sources of energy and do not pursue proper environmental policy. They deal with serious social problems due to which their sustainable competitiveness received lower rating. To be more specific, sustainable competitiveness index for this group dropped by $10 \%$ in comparison with $\mathrm{GCI}^{19}$.

\section{CONCLUSION}

Sustainable development may be considered an oxymoron since recently it has become trendy to use the word 'sustainable' in every possible configuration. Sustainable development may be treated as an absurd idea that someone has produced and that should not be in the centre of economists' attention. It is an undeniable fact that the idea of sustainable development observed on a national, transnational and global levels has already become a concept that is being put into practice. Furthermore, it is believed that social and environmental aspects of development are as important as economic aspect.

The analysis of sustainable competitiveness demonstrated by the groups of states presented in the paper has proven the above. It has not only identified the pillars of sustainable competitiveness, favourable or detrimental to competitive ability developed by particular economies, but also areas in which actions should be taken in order to improve their competitive potential. The analysis conducted in the present article emphasizes the responsibility of the rich countries and developed economies for sustainable social and environmental development on a global scale ${ }^{20}$. Four groups of states have been discussed in the paper. It should be stated that particularly groups no. 1

19 According to IMD World Competitiveness Center, social and environmental factors favourable to the world competitiveness of economies will assume a crucial role in the future. IMD, The Competitiveness Roadmap: 2014-2050, https://www.imd.org/uupload/imd.website/ wcc/Roadmap.pdf (25.10.2013).

${ }^{20}$ Global costs of sustainable development associated with the accomplishment of Millennium Development Goals are estimated at more than USD 280 billion annually. Differences are found between two financing structures, namely based on type or geographical situation. See: J.P. Stijns, Ch. Garroway, V. Atisophon, J. Bueren, G. De Paepe, C. Sanchez, Can we still Achieve the Millennium Development Goals?: From Costs to Policies, Development Centre Studies, OECD Publishing 2012. 
and 2 turned out to be less competitive when social and environmental pillars of competitiveness have been taken into account. In this way, their place in the ranking of competitiveness is low compared to the developed countries. Nevertheless, they benefit e.g. from the degradation of natural environment to the greatest extent (some are major importers of crude oil). Therefore, they should participate in the elimination of negative consequences following from mining and using this natural resource. The rich countries should not forget about intergenerational justice and be aware of their responsibility for social aspect of sustainable development on a global scale. Limited water resources, water conflicts and limited access to drinking water in African countries are problems faced not only by selected economies.

A number of international organizations have attempted to provide mechanisms that would make development increasingly sustainable and longterm so that future generations could benefit from it. However, these organizations should not consider national interest more significant than common interest. Much time will pass before nations and people understand the meaning ad importance of sustainable development. WEF has already contributed to better comprehension of the notion through presenting the concept of sustainable competitiveness. It is different from traditionally understood competitiveness. Nowadays, international competitiveness should not be treated only as economic rivalry among nations, but rather as cooperation aimed at accomplishing goals established within the framework of sustainable development and at the same time respecting national specificity and autonomy.

\section{BIBLIOGRAPHY}

Bieńkowski W., Konkurencyjnośc gospodarki polskiej w przededniu wejścia do Unii Europejskiej. Czy rząd może być bardziej aktywny?, [in:] E. Latoszek (ed.), Unia Europejska wobec procesów integracyjnych. Wyzwania dla Polski, WSHiFM, Warszawa 2000.

Bieńkowski W., Reganomika i jej wptyw na konkurencyjność gospodarki amerykańskiej, Wydawnictwo Naukowe PWN, Warszawa 1995.

Globerman S., Georgopoulos G., Regulation And The International Competitiveness of The U.S. Economy, Mercatus Center at George Mason University, 2012, http:// mercatus.org/sites/default/files/InterntlCompetitiveness_Globerman_v1-0_1.pdf (25.10.2013).

Gorynia M. (ed.), Luka konkurencyjna na poziomie przedsiębiorstwa a przystąienie Polski do Unii Europejskiej, Wydawnictwo AE w Poznaniu, Poznań 2002.

IMD, The Competitiveness Roadmap: 2014-2050, https://www.imd.org/uupload/imd. website/wcc/Roadmap.pdf (25.10.2013). 
Jafarnejad A., Ghasemi R., Abdullahi B., Esmailzadeh A., Relationship between Macroeconomic Environment and Technological Readiness: A Secondary Analysis of Countries Global Competitiveness, „European Journal of Social Sciences”, No. 31/2011.

Kłosiński K., Sektor ustug w procesie podnoszenia konkurencyjności gospodarki, IRWiK, Warszawa 2003.

Misala J., Międzynarodowa konkurencyjnośc gospodarki narodowej, PWE, Warszawa 2011.

Misala J., Międzynarodowa konkurencyjnośc gospodarki narodowej; wybrane aspekty teoretyczne, [in:] Czynniki i miary międzynarodowej konkurencyjności gospodarek w kontekście globalizacji - wstęne wyniki badañ, „Prace i Materiały”, No. 264. Instytut Gospodarki Światowej, Warszawa 2008.

Piontek B., Wspótczesne uwarunkowania rozwoju spoteczno-gospodarczego (ujęcie syntetyczne), „Problemy Ekorozwoju. Problems of Sustainable Development”, Vol. 5, No. 2/2010.

Porter M., Postawy, wartości i przekonania a makroekonomia dobrobytu, [in:] L.E. Harrison, S.P. Huntington (ed.), Kultura ma znaczenie, Wydawnictwo Zysk i S-ka, Warszawa 2003.

Snow M.S., Competition as a discovery procedure, „The Quarterly Journal of Austrian Economics", Vol. 5, No. 3/2002, http://dx.doi.org/10.1007/s12113-002-1029-0.

Stankiewicz M.J., Konkurencyjność przedsiębiorstwa, [in:] M.J. Stankiewicz (ed.), Budowanie konkurencyjności przedsiębiorstwa w warunkach globalizacji, Dom Organizatora, Toruń 2005.

Stijns J.P., Garroway Ch., Atisophon V., Bueren J., De Paepe G., Sanchez C., Can we still Achieve the Millennium Development Goals?: From Costs to Policies, Development Centre Studies, OECD Publishing 2012, http://dx.doi. org/10.1787/9789264173248-en.

Swagel F., International Competiveness, [in:] K.A. Hassett

(ed.), Rethinking Competitiveness, American Enterprise Institute Press, Washington 2012.

Timmer M., Los B., Stehrer R., Rethinking competitiveness: The global value chain revolution, Gaaitzen de Vries 2013, http://www.voxeu.org/article/rethinking-competitiveness-global-value-chain-revolution (26.10.2013).

Toder E., International Competitiveness: Who Competes Against Whom and for What?, Urban-Brookings Tax Policy Center 2012. http://taxpolicycenter.org/ UploadedPDF/412477-international-competitiveness.pdf (24.10.2013).

World Economic Forum, The Global Competitiveness Report 2007-2008, Geneva 2008. World Economic Forum, The Global Competitiveness Report 2011-2012, Genewa 2011. World Economic Forum, The Global Competitiveness Report 2013-2014, Geneva 2013. 